\title{
OPTIMIZATION OF BREWING WASTE'S (TRUB) PHENOLIC COMPOUNDS EXTRACTION BY ULTRASOUND ASSISTED USING RESPONSE SURFACE METHODOLOGY
}

\author{
Bianca C. G. Gandolpho ${ }^{\mathrm{a}, *,(\odot), ~ A l i n e ~ R . ~ A l m e i d a ~}{ }^{\mathrm{a}}$, Gabriel M. Gandolpho ${ }^{\mathrm{b}}$, Daniele Z. Freitas ${ }^{\mathrm{a}}$, Otávio C. Gasparini ${ }^{\mathrm{c}}$, \\ Michelle H. Machado a and Pedro L. M. Barreto ${ }^{\mathrm{a}}$ \\ aDepartamento de Ciência e Tecnologia de Alimentos, Universidade Federal de Santa Catarina, 88034-102 Florianópolis - SC, Brasil \\ bDepartamento de Química, Universidade Federal de Santa Catarina, 88034-102 Florianópolis - SC, Brasil \\ 'Departamento de Ciências Farmacêuticas, Universidade Federal de Santa Catarina, 88034-102 Florianópolis - SC, Brasil
}

Recebido em 07/08/2020; aceito em 04/11/2020; publicado na web em 09/12/2020

\begin{abstract}
The brewing waste, also known as trub, is an abundant by-product of the brewing industry. Such material presents high levels of phenolic compounds, which promote antioxidant, antimicrobial and antifungal effects, turning the trub economically attractive. In this study, the trub's phenolic compounds were extracted by ultrasound-assisted extraction technology. Such experiments were conducted according to a central composite rotatable design (CCRD), with the evaluated parameters being ethanol concentration, solid-liquid ratio and extraction temperature. Response surface methodology (RSM) described the effect of process' variables through second order polynomial models, adjusted appropriately for such analysis, and optimized the operating conditions, aiming to obtain the maximum extraction of phenolic compounds through the proposed technique. The extraction's optimal conditions for the evaluated variables were ethanol concentration of $58 \%$, solid-liquid ratio of $1 \mathrm{~g}$ per $32 \mathrm{~mL}$, and extraction temperature of $36^{\circ} \mathrm{C}$, during a 30 minute process. Considering such experimental conditions, the total amount of phenolic compounds was equal to 7.23 $\mathrm{mg}$ of gallic acid $\mathrm{g}^{-1}$ trub, indicating that a great concentration of phenolic compounds can be extracted from this material through the proposed technique. Thus, this indicates that trub might be a promising by-product that can be used in different industrial fields.
\end{abstract}

Keywords: trub; ultrasound-assisted extraction; response surface; phenolic compounds.

\section{INTRODUCTION}

Phenolic compounds obtained from industry's by-products have been a prominent area of study in recent years, due to the wide number of different properties these compounds can offer, once they are recovered, such as antioxidant, anti-inflammatory, antimicrobial and antifungal activities. ${ }^{1-3}$ Hence, due to their great range of applications, these compounds can be used in the pharmaceutical, cosmetic and food industries. ${ }^{4}$

Other factors that incentivize the recovery and application of these compounds are the increase in the byproduct's value, as well as the decrease in the amount of waste that must be treated after production, which reduces the process environmental impact. In addition to this, environmental and health concerns related to the use of antioxidant and antimicrobial products of synthetic origin also raise the interest in such by-product from low-cost natural sources. ${ }^{1,4}$

During beer production, a large amount of organic waste is obtained, such as brewer's spent grain, trub and residual yeast. ${ }^{5,6}$ In the past few years, studies and applications have been conducted with malt ${ }^{5,7}$ and yeast by-products, ${ }^{5,8}$ however, there is still little information about trub's utility and it's applications, thus, limiting its usage..$^{5,10,11}$

Trub is composed by large amounts of proteins and phenolic compounds, derived from the formation of protein-polyphenol complexes created during its processing, which involves wort boiling after adding the hops. ${ }^{5,10,12,13}$ Among phenolic compounds that create protein complexes, tannins are standing out due their antioxidant, antibacterial and antifungal properties, their function as a coagulating agent and their usage in pharmaceutical industries, as well as their participation in the production of resins and wood adhesives. ${ }^{14}$

Bioactive compounds recovery can be done through different extraction methods. Ultrasound-assisted extraction (UAE) is a

*e-mail: biancacgasparini@gmail.com low-cost and highly efficient method, usually employed in the extraction of phenolic compounds from vegetable sources. ${ }^{15}$ This technique displays short extraction time and requires a lower amount of organic solvents, while also presenting high yields in the extraction of phenolic compounds. ${ }^{16}$

UAE is based on the propagation of ultrasonic waves (20 to $100 \mathrm{kHz}$ through a liquid, causing cavitations to appear, which results in the rupture of cellular membranes. This process improves solvent penetration into the cells, increasing mass transfer and releasing bioactive compounds. ${ }^{15,16}$ Although various studies were conducted using vegetable matter, the optimization of the extraction of phenolic compounds from trub through UAE has not been yet investigated. Considering that the extraction efficiency depends on the raw material and its conditions, the UAE optimization process must be studied for each type of vegetable source. ${ }^{17}$

Bearing in mind the high number of phenolic compounds present in trub, the importance of the recovery of such compounds, as well as the necessity of research that focuses on new ways to utilize industrial by-products, this study seeks to optimize UAE parameters, such as ethanol concentration, extraction temperature, and solid-liquid proportions, through response surface methodology (RSM), making use of a central composite rotatable design (CCRD) in order to obtain the ideal conditions for the extraction of phenolic compounds from trub and determinate total phenolic content (TPC) of this trub extracts.

\section{EXPERIMENTAL PART}

\section{Reagents}

The following reagents were applied on the extraction process and trub's total phenolic content determination: gallic acid (Sigma-Aldrich Co., USA), ethanol (99,5\% v/v) (Synth, São Paulo, Brazil), sodium 
carbonate (PA-ACS, Nuclear, Brazil) and Folin-Ciocalteu (Dinâmica, São Paulo, Brazil).

\section{Sample}

The trub sample were supplied by Brewtime (São José dos Campos, São Paulo, Brazil). The brewer's spent trub was obtained from the brewing of IPA style beer, which was produced using three varieties of malt (Pilsen, Pale Ale and Melanoidin) and three varieties of hops (Cascade, Chinook and Amarillo).

\section{Sample preparation}

Trub samples were frozen at $-70{ }^{\circ} \mathrm{C}$ (Nuaire $80 \mathrm{c}$, USA) for $24 \mathrm{~h}$, then freeze dried (L101 Liotop, Brazil). After that, samples were kept at $-20{ }^{\circ} \mathrm{C}$ and protected from light until the experiments were performed.

\section{Trub's phenolic compounds extraction by ultrasound-assisted method (UAE)}

Ultrasound-assisted extraction was performed using an ultrasonic cleaning bath (Ultronique, model Q5.9137A, Indaiatuba, São Paulo, Brazil). Phenolic extracts from trub samples were obtained accordingly to three independent factors: extraction temperature $\left({ }^{\circ} \mathrm{C}\right)$, solvent concentration $(\%)$ and solid-liquid ratio $\left(\mathrm{g} \mathrm{mL}^{-1}\right)$. These factors were evaluated by 18 tests of the $2^{3}$ factorial experimental design (Table 2). To begin, $1 \mathrm{~g}$ of trub was suspended in a waterethanol solution, following a specific solid-liquid ratio. Solutions were kept in the ultrasonic bath at distinct heating temperatures.

The frequency and duration of the extracting process was fixed at $37 \mathrm{kHz}$, for $30 \mathrm{~min}$. After extraction, the solution was centrifuged (Hermle, model Z200A, Gosheim, Germany) for $25 \mathrm{~min}$ at $1956 \mathrm{~g}$. Supernatant was removed and filtered through Whatman $\mathrm{N}^{\circ} 1$ filter paper under vacuum, with the obtained solution being used in the total phenolic content determination.

\section{Experimental design}

An experimental design was conducted to optimize trub's phenolic compounds extraction based on the ultrasound-assisted technique, adapting Wang et al. ${ }^{18}$ and He et al ${ }^{19}$ propositions. Central composite rotatable design (CCRD) was employed to evaluate the effects and interactions of three extraction variables, allowing to determine which combination was the best to extract trub's phenolics. These independent variables were ethanol concentration $\left(\mathrm{x}_{1}\right)$, extraction temperature $\left(\mathrm{x}_{2}\right)$ and solid-liquid ratio $\left(\mathrm{x}_{3}\right)$, coded in different levels $(-1$ and +1$)$ with a central point $(0)$ and two axial points $(-1,68$ and $+1,68)$, as shown in Table 1 .

Table 1. Independent variables and their coded levels, used in CCRD to optimize trub's phenolic compounds ultrasound-assisted extraction

\begin{tabular}{lccccc}
\hline \multirow{2}{*}{ Variables } & \multicolumn{5}{c}{ Levels } \\
\cline { 2 - 6 } & $-\alpha(-1.68)$ & -1 & 0 & 1 & $\alpha(1.68)$ \\
\hline Ethanol concentration $(\%)$ & 33 & 40 & 50 & 60 & 67 \\
Extraction temperature $\left({ }^{\circ} \mathrm{C}\right)$ & 23 & 30 & 40 & 50 & 57 \\
Solid-liquid ratio $\left(\mathrm{g} \mathrm{mL}^{-1}\right)$ & 22 & 25 & 30 & 35 & 38 \\
\hline
\end{tabular}

This strategy was based on a $2^{3}$ factorial design with eight factorial points, six axial points and four center point replications, allowing for the estimation of experimental error, leading to 18 sets of experiments. Table 2 lists the actual experimental parameters corresponding to the designed levels. All assays were performed in random order and in triplicate to minimize unexpected variability effects on the observed responses.

Response variables were fitted to a second order polynomial model equation (Equation 1), applying response surface methodology (RSM), which was able to describe the relationship between responses and independent variables, providing an ideal model for total phenolic contents (TPC) extraction.

$$
Y=\beta_{0}+\sum_{i=1}^{5} \beta_{i} x_{i}+\sum_{i=1}^{5} \beta_{i i} x_{i}^{2}+\sum_{i=1}^{4} \sum_{j=i+1}^{5} \beta_{i j} x_{i} x_{j}
$$

In the model, $Y$ represents the predicted response, $\beta_{0}$ the constant, $\beta_{\mathrm{i}}$ the quadratic linear regression coefficients, $\beta_{\mathrm{ii}}$ and $\beta_{\mathrm{ij}}$ the linear regression interaction coefficients, $\mathrm{x}_{\mathrm{i}}$ and $\mathrm{x}_{\mathrm{j}}$ the independent variables and $i$ and $j$ the system's coded factors. All coefficients were calculated by regression analysis and their significance was verified using analysis of variance (ANOVA) on STATISTICA 7.0 (Statsoft Inc., Tulsa, OK, USA) statistic software.

\section{Determination of TPC in trub's extracts}

Trub extract's TPC was determined with Folin-Ciocalteu method. ${ }^{20}$ In this technique, $150 \mu \mathrm{L}$ of trub extract solution was added to a test tube and mixed with $7500 \mu \mathrm{L}$ of distilled water and $750 \mu \mathrm{L}$ of Folin-Ciocalteau. After three minutes, $2250 \mu \mathrm{L}$ of sodium carbonate solution $\left(15 \% \mathrm{Na}_{2} \mathrm{CO}_{3}\right)$ and $4350 \mu \mathrm{L}$ of distilled water were added and the mixture, which was then shaken and left to decant at room temperature for two hours, in the dark. The absorbance of the resulting solutions was evaluated at $765 \mathrm{~nm}$ using a SP 2000 spectrophotometer (Bel Photonics ${ }^{\circledR}$, Piracicaba, SP, Brazil). Extract's TPC was expressed as a gallic acid equivalent ( $\mathrm{mg} \mathrm{GAE} \mathrm{g}^{-1}$ trub).

\section{Statistical analysis}

All experiments were carried out in triplicates and its results were expressed as the mean \pm standard deviation (SD). Response surface plots were obtained through STATISTICA 7.0 statistical software (StatSoft, Inc., Tulsa, OK, USA). Data was submitted to both regression and variance analysis (ANOVA) $(\mathrm{p}<0.05)$.

\section{RESULTS AND DISCUSSION}

\section{Determination of total phenolic content (TPC) in trub extracts}

Central composite rotatable design $2^{3}$ (factorial planning) was applied, along with response surface methodology, to optimize the trub's TPC extraction and evaluate the main effects and study factor interactions. The evaluated factors were ethanol concentration (33-67\%), extraction temperature $\left(23-57^{\circ} \mathrm{C}\right)$ and solid-liquid ratio (22-38 $\mathrm{g} \mathrm{mL}^{-1}$ ). Table 2 shows the matrix (CCRD) with the coded and real values, as well as the responses obtained for 18 trials, with the experimental and predicted values of total content of phenolic compounds extracted from trub.

The predicted values of total phenolic content are close to the experimental values, demonstrating that the model is applicable. The maximum phenolic compounds content (7.232 $\mathrm{mg} \mathrm{GAE} \mathrm{g}^{-1}$ trub) was obtained during test number eight, under $60 \%$ ethanol concentration, $50{ }^{\circ} \mathrm{C}$ extraction temperature and $35 \mathrm{~g} \mathrm{~mL}^{-1}$ solidliquid ratio, at a fixed extraction time of $30 \mathrm{~min}$. Lowest phenolic compounds content ( $3.926 \mathrm{mg} \mathrm{GAE} \mathrm{g}^{-1}$ trub) was obtained during experiment number nine. 
Table 2. CCRD of five-level, three independent variables and their experimental and predicted response (dependent variable-total phenolic content)

\begin{tabular}{|c|c|c|c|c|c|}
\hline \multirow{3}{*}{ Assay (CCRD) } & \multicolumn{3}{|c|}{ Independent variables } & \multirow{2}{*}{\multicolumn{2}{|c|}{$\begin{array}{c}\text { Dependent variable } \\
\text { Total phenolic content }^{\mathrm{a}}\end{array}$}} \\
\hline & \multirow{2}{*}{ Ethanol concentration (\%) } & \multirow{2}{*}{ Extraction Temperature $\left({ }^{\circ} \mathrm{C}\right)$} & \multirow{2}{*}{ Sólid/líquid ratio $\left(\mathrm{g} \mathrm{mL}^{-1}\right)$} & & \\
\hline & & & & Experimental $^{\mathrm{b}}$ & Predicted \\
\hline 1 & $40(-1)$ & $30(-1)$ & $25(-1)$ & $5.204 \pm 0.384$ & 5.380 \\
\hline 2 & $40(-1)$ & $30(-1)$ & $35(+1)$ & $4.793 \pm 0.305$ & 4.783 \\
\hline 3 & $40(-1)$ & $50(+1)$ & $25(-1)$ & $5.158 \pm 0.483$ & 5.482 \\
\hline 4 & $40(-1)$ & $50(+1)$ & $35(+1)$ & $5.688 \pm 0.055$ & 5.706 \\
\hline 5 & $60(+1)$ & $30(-1)$ & $25(-1)$ & $7.166 \pm 0.539$ & 7.228 \\
\hline 6 & $60(+1)$ & $30(-1)$ & $35(+1)$ & $7.179 \pm 0.767$ & 6.934 \\
\hline 7 & $60(+1)$ & $50(+1)$ & $25(-1)$ & $6.520 \pm 0.103$ & 6.609 \\
\hline 8 & $60(+1)$ & $50(+1)$ & $35(+1)$ & $7.232 \pm 0.121$ & 7.135 \\
\hline 9 & $33(-1.68)$ & $40(0)$ & $30(0)$ & $3.926 \pm 0.419$ & 3.664 \\
\hline 10 & $67(+1.68)$ & $40(0)$ & $30(0)$ & $6.300 \pm 0.358$ & 6.450 \\
\hline 11 & $50(0)$ & $23(-1.68)$ & $30(0)$ & $6.510 \pm 0.239$ & 6.557 \\
\hline 12 & $50(0)$ & $57(+1.68)$ & $30(0)$ & $6.975 \pm 1.106$ & 6.816 \\
\hline 13 & $50(0)$ & $40(0)$ & $22(-1.68)$ & $7.171 \pm 0.213$ & 6.800 \\
\hline 14 & $50(0)$ & $40(0)$ & $38(+1.68)$ & $6.500 \pm 0.315$ & 6.744 \\
\hline 15 & $50(0)$ & $40(0)$ & $30(0)$ & $6.236 \pm 0.393$ & 6.674 \\
\hline 16 & $50(0)$ & $40(0)$ & $30(0)$ & $6.528 \pm 0.358$ & 6.674 \\
\hline 17 & $50(0)$ & $40(0)$ & $30(0)$ & $7.058 \pm 0.760$ & 6.674 \\
\hline 18 & $50(0)$ & $40(0)$ & $30(0)$ & $6.848 \pm 0.495$ & 6.674 \\
\hline
\end{tabular}

${ }^{a}$ Expressed in mg GAE/g trub, GAE, gallic acid equivalent.

Multiple regression analysis was performed on the experimental data and the model coefficients were evaluated for significance, using Student's t-test. The quadratic (Q) and linear (L) effect of ethanol concentration was significant $(\mathrm{p}<0.05)$, however, the effects of extraction temperature (L) (Q) and solid-liquid ratio (L) (Q), as well as the interaction effects between variables were not significant in this study. Coefficient values are presented in Table 3.

Table 3. Regression coefficient of polynomial model, and tests of the significance for total phenolic compounds extraction of trub a

\begin{tabular}{lcccc}
\hline Variables $^{\mathrm{b}}$ & Coefficient & $\begin{array}{c}\text { Standard } \\
\text { error }\end{array}$ & $\mathrm{t}$ - value & $p$-value \\
\hline intercept & -6.56164 & 7.404059 & -0.88622 & 0.401352 \\
$\mathrm{x}_{1}(\mathrm{~L})$ & 0.66800 & 0.127905 & 5.22263 & 0.000800 \\
$\mathrm{x}_{1}{ }^{2}(\mathrm{Q})$ & -0.00559 & 0.000936 & -5.97483 & 0.000333 \\
\hline
\end{tabular}

${ }^{a}$ Without non significant variables. ${ }^{b}$ Variables $\mathrm{x}_{1}$ : ethanol concentration $(\%)$, $(\mathrm{L})$ : linear coefficients, $(\mathrm{Q})$ : quadratic coefficients.

The determination coefficient $\left(\mathrm{R}^{2}\right)$ of this model is 0.9401 , which indicates that it adequately represents the real relationship between chosen parameters. A quadratic model, built through regression analysis (without insignificant terms), described the mathematic relation between the independent and response variables (Equation 2).

$$
Y=-6.561643+0.667999 x_{1}-0.005594 x_{1}^{2}
$$

According to variance analysis (ANOVA), the regression model can be considered statistically significant under the F-test $(p=0.05)$ since the calculated F-value $\left(\mathrm{F}_{\text {cal }}\right)$ was higher than the critical F-value $\left(F_{\text {tab }}\right)$. Calculated value is over four times greater than the listed value. As a practical rule, a model is statistically significant when the calculated F-value is at least three to five times greater than the critical value. ${ }^{21}$ All ANOVA results are presented in Table 4.

The Pareto chart (Figure 1) allows for a clearer view on the effects of the evaluated variables. ${ }^{22}$ The diagram shows that only ethanol concentration ( $\mathrm{L}$ and $\mathrm{Q}$ ) had a statistically significant effect on the phenolic compounds extraction. The interaction effects between variables and the quadratic and linear effects of extraction temperature and solid-liquid ratio was not relevant on TPC evaluation.

Table 4. Analysis of variance of the second-order total phenolic contents of trub model ${ }^{\mathrm{a}}$

\begin{tabular}{lccccc}
\hline Variables $^{\mathrm{b}}$ & Sum of squares & Degree of freedom & Mean square & F- value & $p$-value \\
\hline $\mathrm{x}_{1}(\mathrm{~L})$ & 9.25944 & 1 & 9.259441 & 71.09 & 0.003501 \\
$\mathrm{x}_{1}{ }^{2}(\mathrm{Q})$ & 4.12649 & 1 & 4.126493 & 31.68 & 0.011090 \\
Lack of fit & 0.53373 & 5 & 0.106747 & 0.82 & 0.606545 \\
Pure error & 0.39072 & 3 & 0.130241 & & \\
Total & 15.45364 & 17 & & \\
\hline
\end{tabular}

${ }^{\mathrm{a}}$ Coefficient of determination $\left(\mathrm{R}^{2}\right)=0.9401 .{ }^{\mathrm{b}}$ Variables $\mathrm{x}_{1}$ : ethanol concentration $(\%)$, (L): linear coefficients, (Q): quadratic coefficients. 


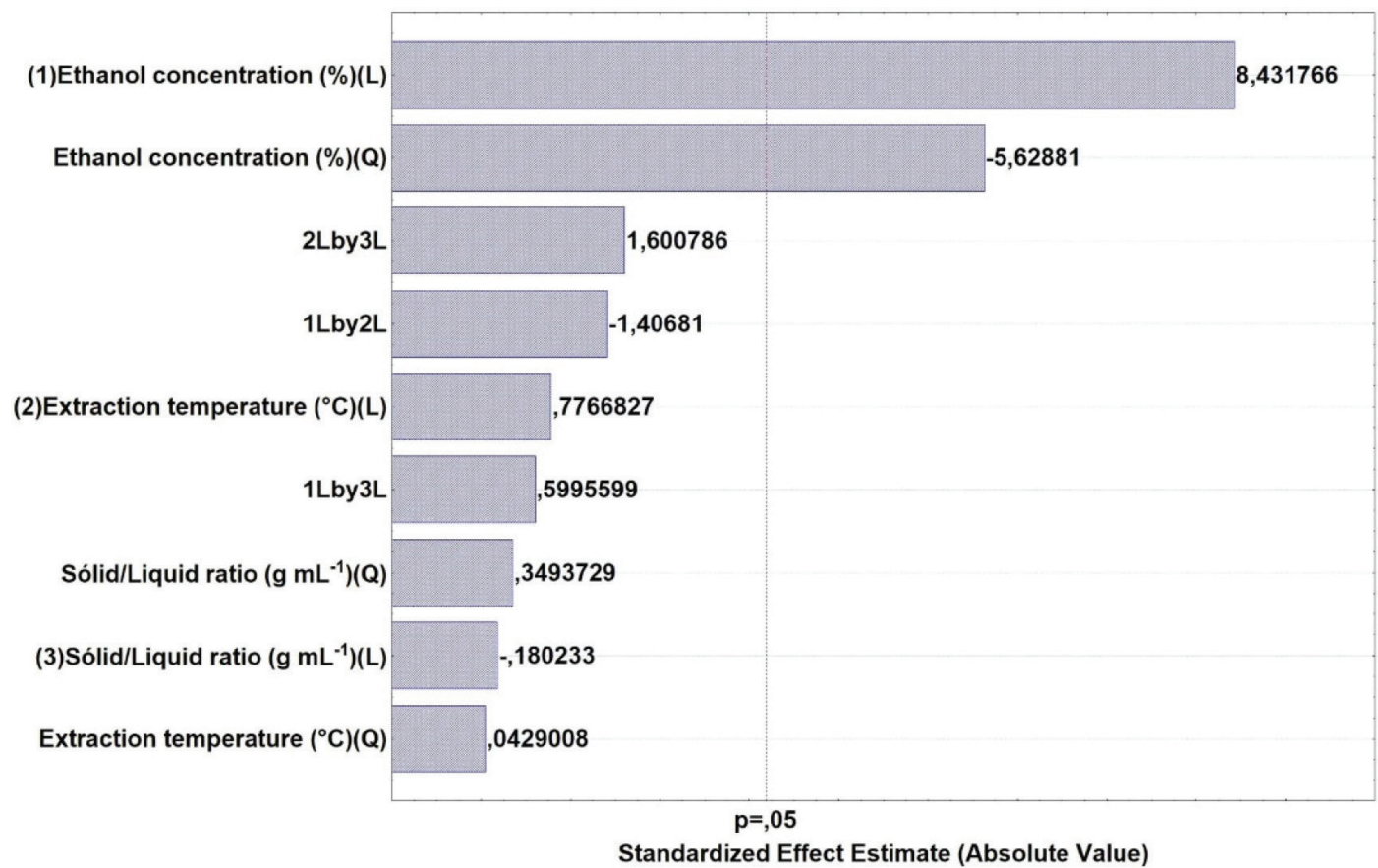

Figure 1. Analysis of the effect of the variables and their interactions by the Pareto plot

\section{Effect of independent variables on TPC on RSM model}

Response surface method was applied to determine the variables optimal levels on trub's phenolics extraction, thus, tridimensional surface plots were constructed, according to Equation 2. The results are shown in Figure 2. Figure 2a shows the effect of ethanol concentration and extraction temperature on TPC. TPC increased gradually, along with ethanol concentration at a given temperature of extraction, reaching maximum values between 55 and 66\%. However, when ethanol concentration was higher than $66 \%$ in the present investigation, the phenolic content slowly decreased.

Similarly, the effect of ethanol concentration and solid-liquid
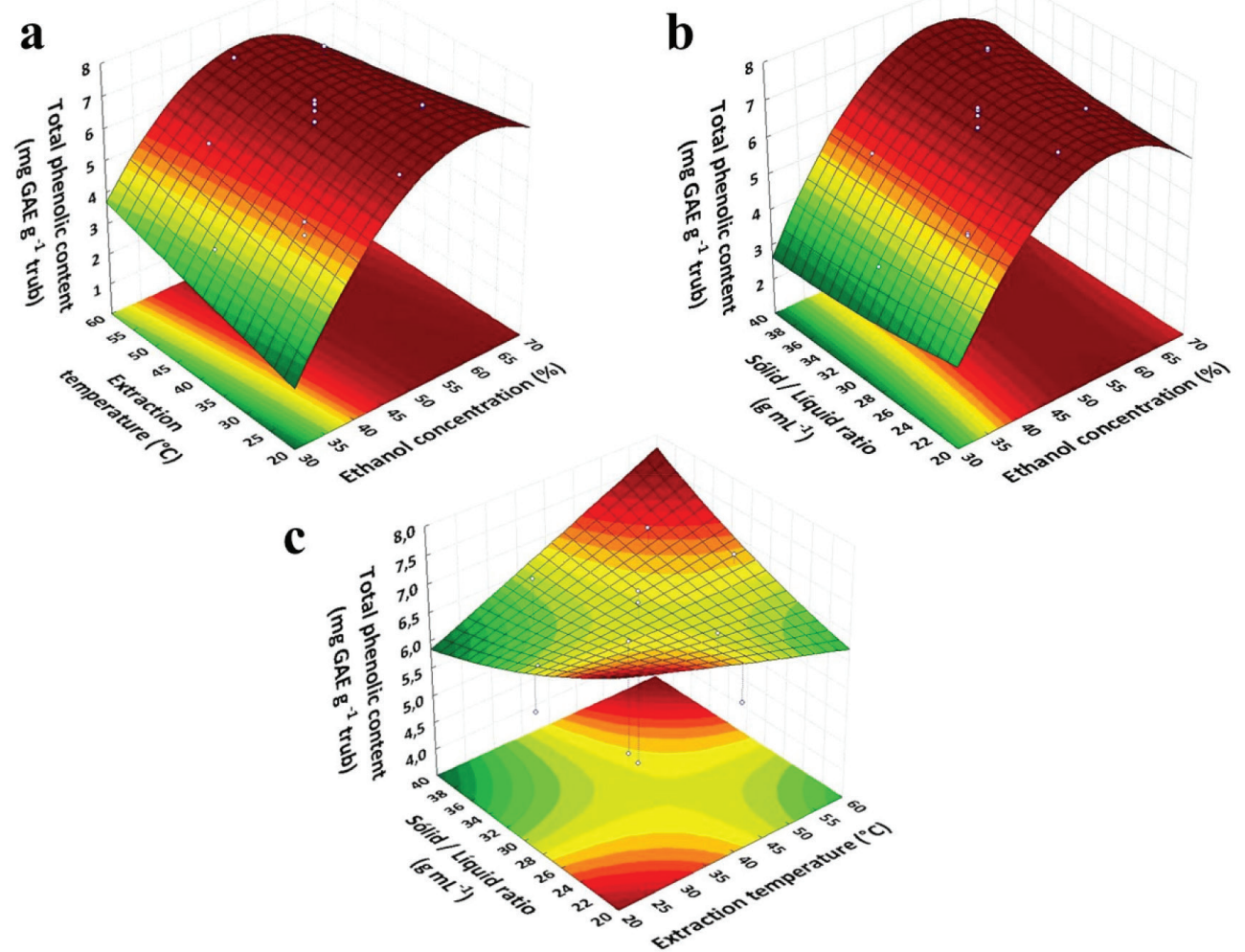

Figure 2. Surface response graph for the effect of different extraction parameters on TPC from trub (a) Effect of ethanol concentration (\%) and extraction temperature $\left({ }^{\circ} \mathrm{C}\right)$. The solid/liquid ratio of extraction is constant in level zero $\left(1 \mathrm{~g} 30 \mathrm{~mL}^{-1}\right)$. (b) Effect of ethanol concentration (\%) and solid/liquid ratio. Extraction temperature $\left({ }^{\circ} \mathrm{C}\right)$ is constant at level zero $\left(40{ }^{\circ} \mathrm{C}\right)$. (c) Effect of extraction temperature $\left({ }^{\circ} \mathrm{C}\right)$ in relation to solid/liquid ratio. The concentration of ethanol is constant in level zero (50\%) 
ratio shown in Figure $2 b$ demonstrated that TPC increased with the slow rise in ethanol concentration at a given solid-liquid ratio, reaching maximum of $65 \%$ ethanol concentration, slowly decreasing when ethanol concentration was higher than $66 \%$. These results are probably related to solvent and bioactive compounds polarities, which directly influences the extraction and separation of such compounds. ${ }^{23}$ The addition of water enhances swelling of the plant material that way increasing the contact surface area between solid material and solvent. ${ }^{24}$ While alcohol breaks the bonds between the phenolic compounds and the sample matrix, increasing the solubility and recovery of these compounds. ${ }^{25,26}$ The increasing ethanol proportion decrease the dielectric constant of the solution, thus reducing the interaction energy between the solute and solvent molecules, providing an increase in the mass transfer by molecular diffusion. ${ }^{27}$

However, the high concentration of ethanol can cause denaturation of cell wall proteins including those that are conjugated to insoluble phenolic compounds, and hinder the dissolution of these compounds and also of the free phenolic compounds present in the cell vacuoles influencing in the extraction process. ${ }^{28}$ So, a proper combination of alcohol with water (or other organic solvents) shows synergistic effect, being more effective in extracting phenolic compounds than alcohol alone..$^{29-31}$

The data found during this study corroborates with the findings of Prasad et al., ${ }^{23}$ where the total polyphenol content of Mangifera pajang Kosterm peels increased from 9.27 to $12.9 \mathrm{mg} \mathrm{GAE} \mathrm{g}^{-1}$ sample when ethanol concentration increased from $32 \%$ to $68 \%$. Spigno et al., ${ }^{32}$ observed higher phenolic contents concentrations from grape seeds when $50 \%$ ethanol was used. Silva et al. ${ }^{33}$ also found a maximum amount of polyphenols extracted from lychee peels using $50 \%$ ethanol.

Živković et al. ${ }^{24}$ also reported that in pomegranate peel extracts, TPC initially increased along with the ethanol concentration, reaching a maximum level at $\sim 40 \%$ ethanol. However, it started to decrease with further increase in ethanol concentration. Lu et al., ${ }^{34}$ obtained a high concentration of phenolic compounds from Wikstroemia root bark using $67 \%$ ethanol. For ethanol concentrations higher than $68 \%$, phenolic content decreased.

Figure $2 \mathrm{c}$ shows that the effects of the solid-liquid ratio and extraction temperature were not relevant for the present study. These results are consistent with those in the Pareto chart, which shows that these parameters and their interactions have no influence on the extraction of phenolic compounds from trub.

Carniel et al., ${ }^{35}$ demonstrated the effects of ethanol percentage versus solid-liquid ratio and temperature versus solid-liquid ratio on TPC from Physalis angulate. In both cases, low solid-liquid ratios and intermediate ethanol percentages, offered a higher yield of TPC.

Nevertheless, the amount of solvent on solid-liquid ratio is an important factor that should be highlighted. The solvent volume should be enough to promote a satisfying hydration and swelling of the solid phase and to reduce the process costs and residual material, since the use of a large amount of solvent is not considered economical for commercial application, due to the high operating cost of solvents and energy consumption in bulky handling in subsequent processes. ${ }^{35,36}$

As well as the solid-liquid ratio, temperature is a parameter of great importance in the extraction of phenolic compounds. ${ }^{26,37}$ Temperature elevation may increase the yield of TPC extraction through the softening and swelling of the plant tissues, and weakening of interactions of insoluble phenolic compounds (phenol-protein and phenol-polysaccharide) interactions, making the cells more permeable, decrease surface tension and increases the diffusion rates. $^{26,37,38}$ The increment of temperature could also decrease viscosity of the extraction medium, increasing mass transfer, as well as phenolics compounds solubility in the solvent. ${ }^{26,37}$

However, a too high temperature, above $50{ }^{\circ} \mathrm{C}$ can cause thermal degradation of certain phenolic compounds and promoting reaction between these compounds and other matrix components. ${ }^{27,39} \mathrm{In}$ addition, high extraction temperature can cause the loss of solvent through volatilization, enhancement of impurities in the phenolic extract, and increase energy costs. ${ }^{26,40}$

Although the solid-liquid ratio and the extraction temperature haven't shown significant effects on TPC, an intermediate value of these variables may be adopted, providing good hydration of the solid phase and preserving thermolabile compounds.

Analyzing the response surfaces, Figure 2, it is possible to observe that the optimal extraction region is located where the highest concentrations of TPC are obtained. As a significant curvature was not observed in Figure 2c, the condition towards the optimal extraction region is sought. However, the realization of new experiments using extreme conditions of temperature, concentration of ethanol and solid-liquid ratio, shifting the experiments towards the optimum condition are not feasible since the maximum extraction temperature applied is already above the temperature indicated for thermosensitive compounds $\left(>50^{\circ} \mathrm{C}\right)$ which can cause the thermal degradation of phenolic compounds and increase the extraction of impurities.

Similarly, an increase in the concentration of ethanol would be impracticable, as it could cause the denaturation of cell wall proteins and make it difficult to dissolve insoluble and free phenolic compounds. In addition, large proportions of solvent in the solidliquid ratio is not considered economical and promotes bulky handling in subsequent processes and high energy costs.

\section{Verification of the predicted optimal extraction conditions}

The optimal conditions obtained using the model were as follows: ethanol concentration, $58 \%$; extraction temperature, $36{ }^{\circ} \mathrm{C}$; and solidliquid ratio of $1 \mathrm{~g}$ to $32 \mathrm{~mL}$. Under optimal conditions, the model predicted a maximum response of $6.99 \mathrm{mg} \mathrm{GAE} \mathrm{g}^{-1}$ trub. To compare the predicted result with the experimental values, experimental rechecking was performed using the optimal conditions. A mean value of $7.57 \pm 0.42 \mathrm{mg} \mathrm{GAE} \mathrm{g}^{-1}$ trub was obtained, and a good correlation between these results confirmed that the response model was adequate to the expected optimization.

Studies about phenolic compounds in trub samples are still sparse in literature. Saraiva et al., ${ }^{11}$ reported approximately values of TPC in trub samples of $3.42 \mathrm{mg} \mathrm{GAE} \mathrm{g}^{-1}$ and $1.28 \mathrm{mg} \mathrm{GAE} \mathrm{g}^{-1}$, less than that found in this study. According to Dos Santos Mathias et al., ${ }^{41}$ in general the average composition of polyphenols of trub sample may be describe as $0.05-0.1 \mathrm{~g}_{\text {polyphenol }} \mathrm{g}_{\mathrm{dw}}{ }^{-1}$ in dry matter. For Kunze, ${ }^{13}$ this composition is described as $0.07-0.08 \mathrm{~g} \mathrm{~g}_{\mathrm{dw}}{ }^{-1}$ of polyphenols in dry matter of trub samples.

This variation can be related with extraction method and/ or agronomic factors of the hops and the malted cereal, that play important roles in the trub phenolic composition. ${ }^{42}$ Almeida et al. ${ }^{43}$ determined the TPC from two hops varieties and reported values of $33.93 \pm 0.67$ to $27.31 \pm 0,98 \mathrm{mg} \mathrm{GAE} \mathrm{g}^{-1}$. In a study by Fărcaş et al. ${ }^{44}$ the TPC of three variations of malt and one brewer's spent grain (BSG) sample were evaluated, obtaining values of $1.48 \pm 0.51 \mathrm{mg} \mathrm{GAE} \mathrm{g}^{-1}$ for Pilsner malt, $2.56 \pm 6.18 \mathrm{mg} \mathrm{GAE} \mathrm{g}^{-1}$ for Caramunich malt, $3.35 \pm 4.41 \mathrm{mg} \mathrm{GAE} \mathrm{g}^{-1}$ for Carafa malt and $2.84 \pm 3.07 \mathrm{mg} \mathrm{GAE} \mathrm{g}^{-1}$ for BSG.

According to Menes et al. ${ }^{45}$ the TPC of BSG using different ethanol concentration varied from $4.26 \pm 0.51$ to $7.13 \pm 0.24 \mathrm{mg} \mathrm{GAE} \mathrm{g}^{-1}$ with $20 \%$ and $60 \%$ ethanol, respectively. Vieira et al. ${ }^{46}$ determined 
the TPC of brewer's spent yeast by HPLC analysis and reported of $0.55 \mathrm{mg} \mathrm{g}_{\mathrm{dw}}{ }^{-1}$ in bound fractions and $0.60 \mathrm{mg} \mathrm{g}_{\mathrm{dw}}{ }^{-1}$ free fractions.

According to the maximum TPC value obtained in the

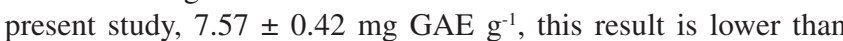
the contents present hops (27-33 $\left.\mathrm{mg} \mathrm{GAE} \mathrm{g}^{-1}\right)^{43}$ for example, but is similar or higher than the phenols content reported to malt variations (3.35-1.48 $\left.\mathrm{mg} \mathrm{GAE} \mathrm{g}^{-1}\right)^{44}$ and to brewer's spent grain (2.84-7.13 $\left.\mathrm{mg} \mathrm{GAE} \mathrm{g}^{-1}\right),{ }^{44,45}$ indicating that trub is a raw material with significant content of phenolic compounds, and consequently with potential application in pharmaceutical, cosmetic and food industries.

\section{CONCLUSIONS}

The ultrasound-assisted technique employed to extract phenolic compounds from trub was effective. The experimental design (CCRD), combined with response surface methodology, was able to describe the effect of the process variables and optimize the best operating conditions in order to maximize the yield of phenolic compounds. Solvent concentration showed strong influence over the extract's phenolic content. The extraction's optimal conditions for the studied variables were $58 \%$ ethanol concentration, solid-liquid ratio of $1 \mathrm{~g}$ to $32 \mathrm{~mL}$ and extraction temperature of $36{ }^{\circ} \mathrm{C}$, with a 30 min extraction time. The present study also indicates that trub can be considered a great source of phenolic compounds, thus revealing its economic potential and range of applications, possibly becoming a promising raw material able to be used in the food, pharmaceutical and cosmetic industries.

\section{ACKNOWLEDGEMENTS}

The authors would like to thank Universidade Federal de Santa Catarina, Coordenação de Aperfeiçoamento de Pessoal de Nível Superior-CAPES (Grant number 1614682) for the financial support, and also Brewtime for providing the trub sample.

\section{REFERENCES}

1. Maestre, R.; Micol, V.; Funes, L.; Medina, I.; J. Agric. Food Chem. 2010, 58, 8365 .

2. Cheng, V. J.; Bekhit, A. E. D. A.; Mcconnell, M.; Mros, S.; Zhao, J.; Food Chem. 2012, 134, 474.

3. Jalalvand, A. R.; Zhaleh, M.; Goorani, S.; Zangeneh, M. M.; Seydi, N. Zangeneh, A.; Moradi, R.; J. Photochem. Photobiol., B 2019, 192 ,103.

4. Fontana, A. R.; Antoniolli, A.; Bottini, R.; J. Agric. Food Chem. 2013, 61,8987

5. Mathias, T. R. S.; Alexandre, V. M. F.; Cammarota, M. C.; De Mello, P. P. M.; Servulo, E. F. C.; J. Inst. Brew. 2015, 121, 400

6. Olajire, A. A.; J. Cleaner Prod. 2020, 256,102817.

7 Mussatto, S. I.; J. Sci. Food Agric. 2014, 94, 1264.

8. Ferreira, I. M. P. L. V. O.; Pinho, O.; Vieira, E.; Tavarela, J. G.; Trends Food Sci. Technol. 2010, 21,77.

9. Puligundla, P.; Mok, C.; Park, S.; Innovative Food Sci. Emerging Technol. 2020, 62, 102350.

10. Nigam, P. S.; Pandey, A.; Biotechnology for agro-industrial residues utilisation: utilisation of agro-residues, Springer Science \& Business Media: Berlin, 2009.

11. Saraiva, B. R.; Anjo, F. A.; Vital, A. C. P.; Silva, L. H. M. D.; Ogawa, C. Y. L.; Sato, F.; Matumoto-Pintro, P.T.; Int. J. Food Sci. Technol. 2019, 54,1247 .

12. Briggs, D. E.; Boulton, C. A.; Brookes, P. A.; Stevens, R.; Brewing: Science and Practice, Woodhead Publishing: Cambridge, 2004.

13. Kunze, W.; Technology Brewing and Malting, international ed., VLB Berlin, 2014.
14. Shirmohammadli, Y.; Efhamisisi, D.; Pizzi, A.; Ind. Crops Prod. 2018 , $126,316$.

15. Montero-Calderon, A.; Cortes, C.; Zulueta, A.; Frigola, A.; Esteve, M. J.; Sci. Rep. 2019, 9, 1.

16. Chemat, F.; Rombaut, N.; Sicaire, A. G.; Meullemiestre, A.; FabianoTixier, A. S.; Abert-Vian, M.; Ultrason. Sonochem. 2017, 34, 540.

17. Aydar, A.Y.; Bagdathiglu, N.; Koseoglu, O.; Grasas y Aceites 2017, $68,189$.

18. Wang, J.; Sun, B.; Cao, Y.; Tian, Y.; Li, X.; Food Chem. 2008, 106, 804.

19. He, B.; Zhang, L. L.; Yue, X. Y.; Liang, J.; Jiang, J.; Gao, X. L.; Yue, P. X.; Food Chem. 2016, 204, 70.

20. Rossy Junior, J. A.; Singleton, V. L.; Am. J. Enol. Vitic. 1965, 16, 144.

21. Rodrigues, S.; Lona, L. M. F.; Franco, T. T.; J. Food Eng. 2006, 75, 433.

22. Nunes, C. A.; Freitas, M. P.; Pinheiro, A. C. M.; Bastos, S. C.; J. Braz. Chem. Soc. 2012, 23, 2003.

23. Prasad, K. N.; Hassan, F. A.; Yang, B.; Kong, K. W.; Ramanan, R. N.; Azlan, A.; Ismail, A.; Food Chem. 2011,128, 1121.

24. Živković, J.; Šavikin, K.; Janković, T.; Ćujić, N.; Menković, N.; Sep. Purif. Technol. 2018, 194, 40.

25. Jayaprakasha, G. K.; Girennavar, B.; Patil, B. S.; Bioresour. Technol. 2008, 99, 4484.

26. Ghitescu, R. B.; Volf, I.; Carausu, C.; Buhlmannb, A.; Gilcaa, L. A.; Popaa, V. I; Ultrason. Sonochem. 2015, 22, 535.

27. Cacace, J. E.; Mazza, G.; J. Food Eng. 2003, 59, 379.

28. Chen, X.; Wu, X.; Chai, W. M.; Feng, H. L.; Shi, Y.; Zhou, H. T.; Chen, Q. X.; J. Zhejiang Univ., Sci., B 2013, 14, 903.

29. Markom, M.; Hasan, M; Daud, W. R. W.; Singh, H.; Jahim, J. M.; Sep. Purif. Technnol. 2007, 52, 487.

30. Sharmila, G.; Nikitha, V. S.; Ilaiyarasi, S.; Dhivya, K.; Rajasekar, V.; Kumar, N. M.; Muthukumaran, K.; Muthukumaran, C.; Ind. Crops Prod. 2016, 84, 13 .

31. Jovanović, A. A.; Đorđević, V. B.; Zdunić, G. M.; Pljevljakušić, D. S.; Šavikin, K. P.; Gođevac, D. M.; Bugarski, B. M.; Sep. Purif. Technol. 2017, 179, 369

32. Spigno, G.; Tramelli, L.; De Faveri, D. M.; J. Food Eng. 2007, 81, 200.

33. Silva, C.; Garcia, V. A. S.; Franciscato, L. M. S. S.; Revista Ciências Exatas e Naturais 2016, 8, 81.

34. Lu, C. L.; Li, Y. M.; Fu, G. Q.; Yang, L. I.; Jiang, J. G.; Zhu, L.; Lin, F. L.; Chen, J.; Lin, S. Q.; Food Chem. 2011, 124,1500.

35. Carniel, N.; Dallago, R. M.; Bilibio, D.; Nunes, A. L.; Bender, J. P.; Priamo, W. L.; Acta Sci., Technol. 2018, 40, 35530.

36. Pradal, D.; Vauchel, P.; Decossin, S.; Dhulster, P.; Dimitrov, K.; Ultrason. Sonochem. 2016, 32, 137.

37. Arruda, H. S.; Pereira, G. A.; Pastore, G. M.; Food Anal. Methods 2017, 10, 100 .

38. Bachir Bey, M.; Meziant, L.; Benchikh, Y.; Louaileche, H.; Food Chem. 2014, 162,277

39. Yim, H. S.; Chye, F. Y.; Rao, V.; Low, J. Y.; Matanjun, P.; How, S. E.; Ho, C. H.; J. Food Sci. Technol. 2013, 50, 275.

40. Liu, Q. M.; Yang, X. M.; Zhang, L.; Majetich, G.; J. Med. Plants Res 2010, 4, 2503

41. Dos Santos Mathias, T. R.; De Mello, P. P. M.; Sérvulo, E. F. C.; J. Brew. Distill. 2014, 5, 1

42. John, J. A.; Shahidi, F.; J. Funct. Foods 2010, 2, 196.

43. Almeida, A. D. R.; Maciel, M. V. D. O. B.; Machado, M. H.; Bazzo, G. C.; De Armas, R. D.; Vitorino, V. B.; Vitali, L.; BlocK, J. M.; Barreto, P. L. M.; Int. J. Food Sci. Technol. 2020, 55, 340.

44. Fărcaş, A. C.; Socaci, S. A.; Dulf, F. V.; Tofană, M.; Mudura, E.; Diaconeasa, Z.; J. Cereal Sci. 2015, 64, 34.

45. Meneses, N. G.; Martins, S.; Teixeira, J. Á.; Mussatto, S. I.; Sep. Purif Technol. 2013, 108,152.

46. Vieira, E. F.; Carvalho, J.; Pinto, E.; Cunha, S.; Almeida, A. A.; Ferreira, I. M.; J. Food Compos. Anal. 2016, 52, 44. 